\title{
Synoptic Weather Types and Long-range Transport Patterns for Ozone Precursors during High-ozone Events in Southern Sweden
}

\begin{abstract}
We studied long-range transport patterns and related weather types in relation to high-ozone events in southern Sweden. The aim was to deepen the understanding of the relationship between Lamb-Jenkinson weather types and surface ozone concentration variation, thus widening the application of the weather type analysis of air quality at 4 sites in this region. The long-range transport patterns associated with high-ozone events were classified into trajectories from Western Europe, Eastern Europe, and in the vicinity of southern Sweden (VIC). The VIC type, characterized by short and whirling curves, represented more than $40 \%$ of the high-ozone events at the studied rural sites. More than half of the high-ozone events occurred under high-pressure conditions, belonging to weather type $\mathrm{A}$ (anticyclones). The high correlation coefficient between annual counts of weather type $A$ and those of long-range transport pattern VIC confirmed the strong link between stagnant weather conditions and high-ozone events, especially during the summer. Furthermore, a strong linear anticorrelation was detected between high-ozone events and annual counts of weather type $\mathrm{C}$ (cyclones) during the summer. This relationship implies that the frequency of weather type $\mathrm{C}$ is a useful indicator for low risk of summertime highozone events in southern Sweden. Moreover, the relationship between the weather type and high ozone risk may be useful in examining the potential effect of climate change on the regional air quality.
\end{abstract}

\section{INTRODUCTION}

An increase of surface ozone, a threat to human health and vegetation, has been observed on a large geographical scale (15). In the Nordic countries, a rising trend in the yearly or seasonal mean ozone concentrations of +0.3 to $+0.5 \mathrm{ppb}$ ozone $\mathrm{yr}^{-1}$ has been detected during the last 10-15 yr $(3,6)$. From 1990 to 2000 , reductions in the anthropogenic emissions of nitric oxide and volatile organic compounds by $24 \%$ and $33 \%$, respectively, were achieved in Europe $(7,8)$. Consequently, a reduction in peak ozone values of the order of $15 \mathrm{ppb}$ due to European emission reductions during the 1990s was predicted for the Nordic countries (8). However, increasing air temperatures as well as reduced cloudiness and precipitation due to climate change may promote high-ozone concentrations (9). It has been suggested that extreme ozone episodes of the kind recorded in the summer of 2003 will become a more common phenomenon in the future due to climate change (8). Increased biogenic emissions (isoprene) and reduced deposition due to lower ozone uptake by plants in a warmer and dryer climate can significantly contribute to extreme ozone episodes (10). The effect of climate change may gradually outweigh the benefit of the emission abatement in Europe for summertime ozone (10).
The climate change feedback on air pollution is causing policy development in Europe to take a new direction (11).

Ozone and its precursors can be transported long distances in free troposphere (12). Hence, they can be accumulated far away from the sources under certain meteorologic conditions. Horizontal advection can also influence surface ozone (13), especially during the summer (14). In the Nordic countries, elevated ozone concentrations are mostly due to long-range transport of ozone and ozone precursors generated further south in the European continent $(3,8)$, whereas the contribution of domestic emissions is believed to be rather small. A sourcereceptor analysis with the model FLEXPART conducted for 3 sites in northern Fennoscandia showed that southern continental Europe can be an important source of polluted air masses associated with the enhanced ozone (15).

The ozone concentration depends on the in situ synoptic weather pattern. A recent study quantified the relationships between synoptic weather types and regional ozone variations in southern Sweden by using Lamb-Jenkinson weather types (16). However, the static nature of the weather type approach does not readily provide data on back trajectories for polluted air masses originating from distant sources (17). The aim of this study was to identify the links between the weather types and long-range transport patterns under high ozone events, defined as situations with a daily maximum 8-hr moving average larger than $50 \mathrm{ppb}$, in southern Sweden.

\section{MATERIALS AND METHODS}

\section{Ozone Data}

Four monitoring sites with long records of hourly ozone concentrations were used in this study: Aspvreten, Rörvik/Råö, Norra Kvill, and Vavihill. The sites are situated in rural areas of southern Sweden and represent regional background ozone concentrations. Aspvreten $\left(58.48^{\circ} \mathrm{N}, 17.23^{\circ} \mathrm{E}, 20 \mathrm{~m}\right.$ above sea level) is situated in an open Scots pine forest $1 \mathrm{~km}$ from the Baltic Sea coast. The site Rörvik/Råö was first positioned at Rörvik $\left(57.40^{\circ} \mathrm{N}, 11.92^{\circ} \mathrm{E}\right)$ and was then moved $2 \mathrm{~km}$ southward to Råö $\left(57.25^{\circ} \mathrm{N}, 11.56^{\circ} \mathrm{E}\right)$ on 1 January 2002 . Both sites are located on the Swedish west coast. Rörvik is positioned approximately $500 \mathrm{~m}$ from the seashore, and Råö is located right at the seashore. Vavihill $\left(56.01^{\circ} \mathrm{N}, 13.09^{\circ} \mathrm{E}, 175 \mathrm{~m}\right.$ above sea level) is situated on the southern slope of a ridge surrounded by a mixed beech forest. Norra Kvill $\left(57.49^{\circ} \mathrm{N}, 15.34^{\circ} \mathrm{E}, 261 \mathrm{~m}\right.$ above sea level) is an inland site in central southern Sweden, positioned high in the local landscape. As monitoring sites in the European Monitoring and Evaluation Programme network, Rörvik/Råö, Norra Kvill, and Vavihill provide high-quality data and have a small percentage of missing values between 1990 and 2006, whereas Aspvreten has a large number of missing values in the early 1990s. Therefore, hourly ozone concentrations at Rörvik/Råö, Norra Kvill, and Vavihill were used to study the relationship between synoptic weather 
patterns and high-ozone events in a longer time series from 1990 to 2006. For cluster analysis of trajectories, hourly data from Rörvik/Råö, Aspvreten, and Vavihill from 1996-2005 were used, because the 3-dimensional trajectory data are only available for these 3 sites starting from 1996 (18).

\section{Lamb-Jenkinson Weather Types}

Lamb-Jenkinson weather types, one of the classification methods of atmospheric circulation, is based on the manual scheme developed by Lamb (19) for the British Isles and then automated by Jenkinson and Collison (20). The Lamb weather types (LWTs) were introduced by Chen (21) for southern Sweden to investigate the impact of atmospheric circulation on winter temperature in southwestern Sweden. Based on mean sea level pressure (MSLP) data at 16 grid points, 6 circulation indices were calculated: indices $\mathrm{u}$ and $\mathrm{v}$ represent westerly and southerly components of the geostrophic wind, index $\mathrm{V}$ is the combined wind speed, indices $\zeta_{u}$ and $\zeta_{v}$ represent westerly and southerly shear vorticity, and $\zeta$ is the total shear vorticity index. The indices have units of $\mathrm{hPa} 10^{\circ-1}$ longitude at the central latitude. Tang et al. (16) described the LWTs calculation scheme used in this study in detail. Following the specific scheme, 8 directional flow types (north, N; northeast, NE; east, E; southeast, SE; south, S; southwest, SW; west, W; northwest, NW), 2 nondirectional types (anticyclonic, A; cyclonic, C), and 16 hybrid types (any combination of 1 directional type and 1 nondirectional types) were included. In this study, the 26 LWTs were grouped into 3 categories based on vorticity, namely, anticyclonic (Av), cyclonic (Cv), and directional (Dv) types. Av and $\mathrm{Cv}$ types incorporated both main and directional hybrid types, and there were 8 Dv types.

Lamb weather types were calculated using 2 MSLP databases with separate time series and data sources for different purposes. Lamb weather types over southern Sweden from 1990-2006 were based on the daily MSLP from NCEP reanalysis data I with $2.5^{\circ}$ latitude by $2.5^{\circ}$ longitude grids (22). Lamb weather types over southern Sweden from 1850 to 2003 were based on the daily MSLP from the European and North Atlantic daily to MULtidecadal climATE variability (EMULATE) project (23).

\section{Long-range Transport Patterns Associated with High-ozone Events}

Trajectory Calculation and Variance Test. Backward trajectory analysis is a valuable tool for determining the transport patterns of air parcels arriving at particular locations at a specific time and provides a useful means of establishing source-receptor relationships of air pollutants. In this study, the backward trajectories at Aspvreten, Rörvik/Råö, and Vavihill from 1996-2005 were calculated by the FLEXTRA trajectory model $(24,25)$. The model was driven by the European Centre for Medium-Range Weather Forecasts (26) meteorologic data with a spatial resolution of $1.25^{\circ}$ and a temporal resolution of 6 hr. Three-dimensional trajectories were calculated using the vertical wind from the European Centre for Medium-Range Weather Forecasts analysis. For the calculated single trajectory, 4-d back trajectory with each 3-hr interval at $500 \mathrm{~m}$ above sea level was used. Thirty-two endpoints $([4 \mathrm{~d} \times 24 \mathrm{hr}] / 3 \mathrm{hr}=32)$ were expressed in Cartesian latitude and longitude coordinates. However, single trajectories can exhibit a considerable amount of error: truncation errors, interpolation errors, wind field errors, errors resulting from certain assumptions regarding the vertical wind, starting position errors, amplification of errors, and ensemble methods (27). One way to reduce the errors associated with a single trajectory is to reconstruct and analyze a large number of atmospheric trajectories $(28,29)$ and group daily trajectories according to the common path that the air masses followed (27). Therefore, 4 6-hr trajectories with ending times of $00.00,06.00,12.00$, and $18.00(\mathrm{GMT}+1)$ for each day were extracted. However, these 6-hr trajectories can vary considerably during the course of the day. A spatial variance test is necessary for the 6-hr trajectories for a certain day to utilize only days during which the air mass arriving at the observation site traveled over the same geographic region. For each observation day, a trajectory matrix was created:

$$
\text { Trajectory date }_{\text {dat }}=\left\{\begin{array}{cccc}
\theta_{01}^{0000} & \theta_{01}^{0600} & \theta_{01}^{1200} & \theta_{01}^{1800} \\
\cdot & \cdot & \cdot & \cdot \\
\theta_{32}^{0000} & \theta_{32}^{0600} & \theta_{32}^{1200} & \theta_{32}^{1800}
\end{array}\right\}
$$

$\theta_{\text {endingtime }}^{\text {end }}$ are the polar coordinates transformed from the Cartesian coordinates at each endpoint for each ending time. The variance $\left(\partial_{\text {endpoint }}^{2}\right)$ was calculated for each endpoint and averaged to get the mean variance of that day.

$$
\text { Variance }_{\text {date }}=\left(\partial_{01}^{2}+\partial_{02}^{2}+\cdots+\partial_{32}^{2}\right) / 32
$$

If the mean variance for a particular day is low, it is reasonable to assume that these 6-hr trajectories follow almost the same path. They were then combined into a single trajectory for that day by taking the average of trajectory endpoints. On the other hand, if the mean variance of that day is high, that day was excluded from further analysis. In this study, a threshold of the variance in trajectories $0.8^{\circ 2}$ was chosen after subjective inspection and comparison (30). As a result, 340 trajectories (72\%) passed the variance test at Rörvik/Råö, 351 trajectories (76\%) at Vavihill, and 374 trajectories (74\%) at Aspvreten.

Two-Stage Clustering. Cluster analysis is a multivariate statistical technique that splits a dataset into a number of groups (27). In this study, an automated K-means clustering algorithm, which calculates squared Euclidean distances (Eq. 3), was used to group the averaged daily trajectories (Matlab ver. 7.2):

$$
\operatorname{Dist}(A, B)=\sum_{k=0}^{32}\left[\left(x_{k}^{A}-x_{k}^{B}\right)^{2}+\left(y_{k}^{A}-y_{k}^{B}\right)^{2}\right] \quad \text { Eq. } 3
$$

where $x$ and $y$ represent the latitude and longitude, respectively, for endpoints A and B.

The trajectory cluster technique is strongly influenced by trajectory length. Short trajectories and trajectories with very curvy paths were sometimes grouped together, although they came from very different regions because the Euclidean distance between initial trajectory points was relatively small. Borge et al. (31) have developed and applied a 2-stage clustering methodology to back trajectories for urban particle studies. The trajectory clusters with unclear directionality identified in the initial cluster analysis (first-stage) were grouped together and reanalyzed following the same methodology (second-stage). This method can assist to capture the influence of short, slowmoving trajectories on local air quality. In this study, the second-stage clustering was applied for each initial cluster to achieve more specific clusters.

\section{RESULTS}

\section{Lamb Weather Types and Diurnal Variation of Surface Ozone}

The diurnal cycle patterns of ozone concentrations under the different weather types are presented in Figure 1. Compared with the averaged diurnal variation under all types, daytime ozone concentrations were higher under weather type A due to 

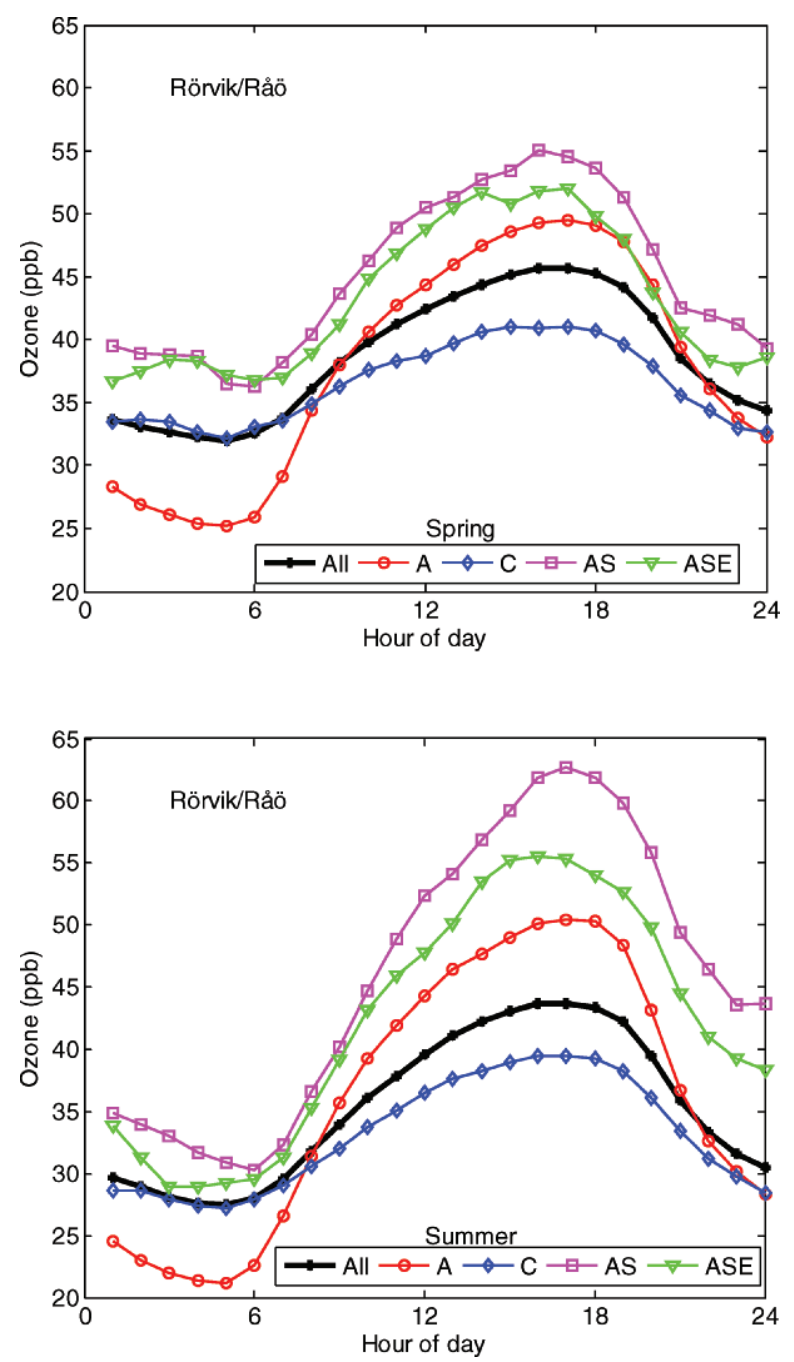

Figure 1. The mean hourly ozone concentrations calculated for spring (April-May) and summer (June-August) for the period 19902005 under all the weather types and weather type A (anticyclone), C (cyclone), AS (anticyclone combined with southerly wind flow), and ASE (anticyclone combined with southeasterly wind flow) at Rörvik/ Råo. Time is GMT +1 .

stronger photochemical production. Conversely, ozone concentrations are lower under weather type $\mathrm{C}$ because of stronger dispersion and/or dilution associated the unstable weather conditions. Weather types AS and ASE represent the highpressure system combined with wind flow from the south and
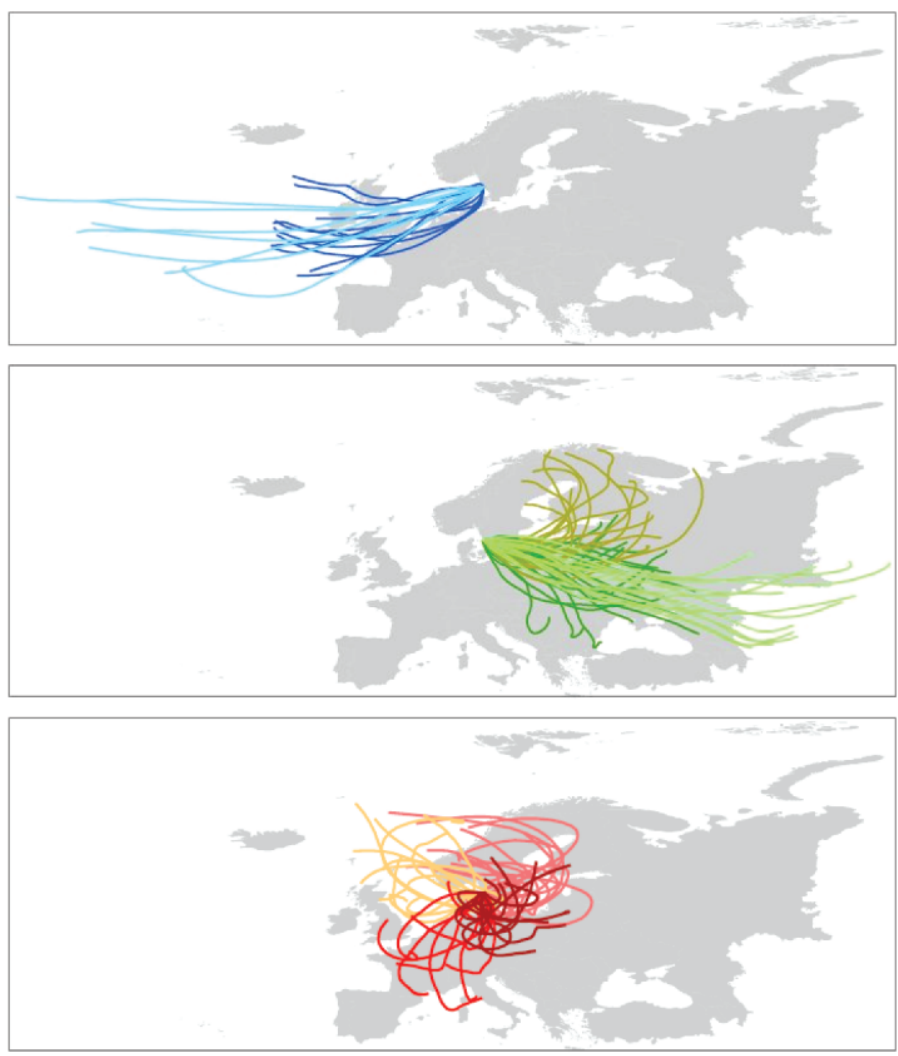

Figure 2. Long-range transport patterns associated with high-ozone events in southern Sweden. The first-stage cluster Western Europe (WE) is presented in blue, the Eastern Europe (EE) cluster in green, and in the vicinity of southern Sweden (VIC) cluster in red. The second-stage clusters are shown in different colors: WEs and WEI represent short and long air mass paths crossing Western Europe, respectively; EEs and EEI represent short and long second-stage clusters passing Eastern Europe, respectively; EEbas grouped the trajectories originating in or taking $4 \mathrm{~d}$ to cross the Baltic areas. VICwe, VICbas, VICnW, and VICee represent the trajectories originating in or passing Western Europe, the Baltic areas, Norway or the North Sea, and Eastern Europe, respectively.

southeast directions, respectively. The higher daytime and nighttime ozone concentrations under AS and ASE indicate an extra input due to long-range transport of ozone and its precursors from potential emission sources in the European continent. The diurnal variation of the ozone concentration under the major weather types was more pronounced in summer than in spring.

Table 1. Frequency (\%) of 2-stage clusters at Aspvreten, Rörvik/Råö, and Vavihill in the spring and summer of 1996-2005.

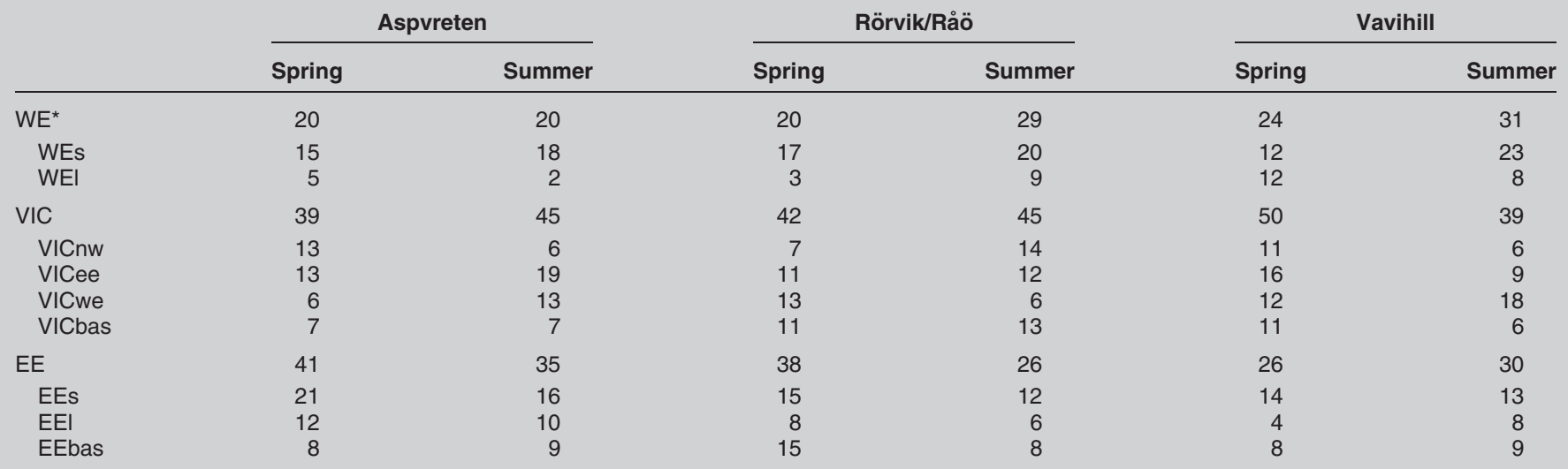

* $W E=$ trajectories passing over Western Europe; WEs = short, straight WE; WEI = Iong, straight WE; VIC = trajectories passing over the vicinity of southern Sweden; VICnW = VIC originating in or passing Norway or the North Sea; VICee = trajectories originating in or passing Eastern Europe; VICwe = trajectories originating in or passing Western Europe; VICbas = trajectories originating in or passing the Baltic areas; $\mathrm{EE}=$ trajectories passing over Eastern Europe; $\mathrm{EEs}=$ short, straight EE; EEI = long, straight EE; EEbas = Baltic area EE. 
Table 2. Correlation coefficients for detrended annual counts of trajectory clusters and those of high-pressure systems (Av, anticyclonic and its hybrid types) and low-pressure systems (Cv, cyclonic and its hybrid types) at Rörvik/Råö (RV), Aspvreten (AP), and Vavihill (VH) in the spring (April-May) and summer (June-August) of 1996-2005.

\begin{tabular}{|c|c|c|c|c|c|c|c|c|c|}
\hline & \multicolumn{3}{|c|}{ WE } & \multicolumn{3}{|c|}{ VIC } & \multicolumn{3}{|c|}{ EE } \\
\hline & RV & AP & VH & RV & AP & VH & RV & AP & VH \\
\hline \multicolumn{10}{|c|}{ Spring } \\
\hline $\begin{array}{l}\mathrm{Cv} \\
\mathrm{Av}\end{array}$ & $\begin{array}{r}0.02 \\
-0.02\end{array}$ & $\begin{array}{r}-0.34 \\
0.18\end{array}$ & $\begin{array}{r}0.23 \\
-0.19\end{array}$ & $\begin{array}{c}-0.001 \\
0.04\end{array}$ & $\begin{array}{r}-0.31 \\
0.58\end{array}$ & $\begin{array}{r}-0.20 \\
0.18\end{array}$ & $\begin{array}{r}-0.42 \\
0.30\end{array}$ & $\begin{array}{r}-0.47 \\
0.39\end{array}$ & $\begin{array}{r}-0.73 \\
0.64\end{array}$ \\
\hline \multicolumn{10}{|c|}{ Summer } \\
\hline $\begin{array}{l}\mathrm{Cv} \\
\mathrm{Av}\end{array}$ & $\begin{array}{r}-0.54 \\
0.70\end{array}$ & $\begin{array}{r}-0.39 \\
0.41\end{array}$ & $\begin{array}{r}-0.47 \\
0.59\end{array}$ & $\begin{array}{c}-0.94^{\star} \\
0.82^{\star \star}\end{array}$ & $\begin{array}{r}-0.83^{\star \star} \\
0.82^{\star \star}\end{array}$ & $\begin{array}{r}-0.82^{\star *} \\
0.83^{\star *}\end{array}$ & $\begin{array}{r}-0.51 \\
0.41\end{array}$ & $\begin{array}{r}-0.68 \\
0.60\end{array}$ & $\begin{array}{r}-0.54 \\
0.40\end{array}$ \\
\hline
\end{tabular}

\section{Long-range Transport Patterns Associated with High-ozone Events}

Two-Stage Clusters. Three first-stage clusters for highozone events were obtained: Western Europe (WE), Eastern Europe (EE), and in the vicinity of southern Sweden (VIC). Each first-stage cluster was then reanalyzed following the same methodology, and several second-stage clusters that were specific in length and curve were obtained. With Rörvik/Råö used as an example, Figure 2 illustrates these 2-stage clusters. The short, straight trajectories represent air masses moving relatively slow and traveling a shorter distance. For example, WEs and EEs passing Western Europe and Eastern Europe, respectively. The relatively long, straight trajectories, such as WEl and EEl, indicate those fast-moving air masses crossing a longer distance over $4 \mathrm{~d}$. The curved trajectories have apparent changes of moving direction. For example, EEbas grouped the trajectories originating north of the Baltic areas that then turned around and crossed Eastern Europe, finally arriving at Rörvik/Råö. Compared with WE and EE, VIC is characterized by shorter and whirling curves and has 4 second-stage clusters: VICwe, VICbas, VICnw, and VICee. "We," "bas," "nw," and "ee" denote the trajectories originating in or passing Western Europe, the Baltic areas, Norway or the North Sea, and Eastern Europe, respectively. In general, long-range transport patterns for Rörvik/Råö, Vavihill, and Aspvreten were quite similar, despite the differences in trajectory length and frequency (Table 1). More high-ozone events were associated with VIC and

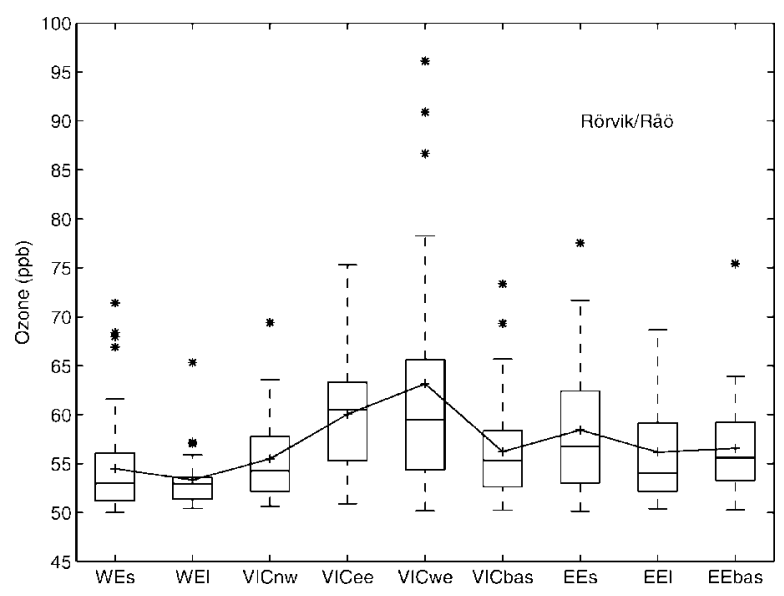

Figure 3. Box plot of daily maximum of 8-hr moving average (ppb) at Rörvik/Råö for the 7 second-stage clusters: WEs, WEI, VICwe, VICbas, VICnw, VICee, EEs, and EEI. The box has lines at the 25th percentile, median, and 75th percentile. The crosses $(+)$ represent the mean value. The whiskers are lines extending from each end of the box to show the extent of the rest of the data. The stars $\left(^{*}\right)$ represent outliers that represent data with values beyond the ends of the whiskers. usually occurred during summer. However, the highest frequency of VIC was found in the spring at Vavihill, and more springtime high-ozone events belonged to EE at Aspvreten.

Ozone Levels under Different Clusters. The box plot of the daily maximum of the 8-hr moving average for each secondstage cluster shows the differences in mean values, median, 25 th percentile, 75th percentile, and outliers (Fig. 3). The secondstage clusters with relative short-length trajectories (e.g., WEs, EEs) were usually associated with high mean and maximum ozone values, confirming the influence of short and slowmoving trajectories on regional air quality.

The first-stage cluster in the vicinity of southern Sweden occurred more frequently during high-ozone events compared with EE and WE: $43 \%$ at Rörvik/Råö, $45 \%$ at Vavihill, and $42 \%$ at Aspvreten. The short and whirling trajectories in VIC indicate a stagnant atmospheric situation with a stable air mass parking over the same region for a long time, usually associated with a persistent high-pressure system. In particular, VICwe, with air masses stagnating over Western Europe, was related to the highest ozone levels, both in terms of means and maxima (Fig. 3). For example, for one high-ozone event on 20-21 June 2000 with a daily 8-hr maximum of 107 ppb at Rörvik/Råö and $110 \mathrm{ppb}$ at Vavihill, the air mass could be traced back to France, Belgium, The Netherlands, and Denmark.

\section{Long-range Transport Patterns and Synoptic Weather Types from 1996 to 2005}

It has been demonstrated that back trajectory clusters arriving at a specific location can serve as a surrogate for different synoptic circulation patterns $(32,33)$ and vice versa. To relate the long-range transport patterns to synoptic weather types in southern Sweden, we investigated the 3 grouped LWTs and the 3 long-range transport clusters (WE, EE, and VIC) for the period 1996 to 2005. The 3 grouped LWTs are Av (anticyclonic and its hybrid types), Cv (cyclonic and its hybrid types), and Dv (directional weather types), representing high-pressure systems, low-pressure systems, and synoptic wind systems, respectively. High-pressure systems (Av) were most common during high-

Table 3. Correlation coefficients of detrended annual counts of a high-ozone event (Nhigh) and the annual mean daily maximum 8hr moving average (M8hrm, unit: ppb) at Rörvik/Råö, Norra Kvill, and Vavihill with annual counts of the weather type Cv (cyclonic and its hybrid types) in summer (June-August) over the period 1990-2006.

\begin{tabular}{lccc} 
& Rörvik/Råö & Norra Kvill & Vavihill \\
\hline Cv vs. Nhigh & $-0.85^{*}$ & $-0.69^{* *}$ & $-0.72^{* *}$ \\
Cv vs. M8hrm & $-0.85^{*}$ & $-0.76^{*}$ & $-0.77^{*}$ \\
${ }^{*}$ significance $=\mathrm{P}<0.001$. ${ }^{* *}$ significance $=\mathrm{P}<0.01$. & \\
\hline
\end{tabular}



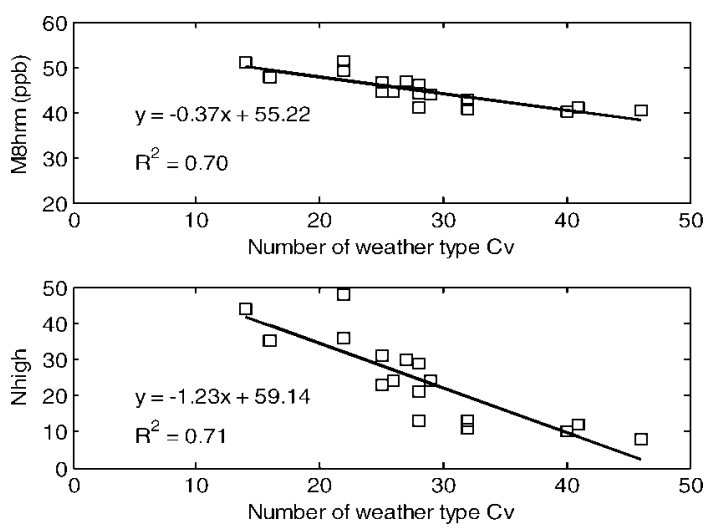

Figure 4. Scatter plot for the annual counts of weather type $\mathrm{Cv}$ (cyclonic and its hybrid types), the annual counts of high-ozone events (Nhigh), and the mean daily maximum 8-hr moving average on high-ozone events (M8hrm, unit: $\mathrm{ppb}$ ) at Rörvik/Råö during the summer (June-August 1990-2006). The linear regression line, regression function, and explained variance $\left(R^{2}\right)$ are shown.

ozone events. Fifty-two percent of the high-ozone events occurred under Av conditions at Rörvik/Råö, 57\% at Aspvreten, and $55 \%$ at Vavihill. It is consistent with the present understanding of ozone formation that sunny, dry, and calm weather conditions under high-pressure system are favorable for ozone photochemical production and that short, whirling trajectories are common under atmospheric stagnation. On the other hand, nearly $20 \%$ of the high-ozone events were associated with low-pressure systems (Cv) and about 30\% with directional types (Dv). The $20 \%$ of high-ozone events associated with $\mathrm{Cv}$ were usually related to the second-stage clusters with short trajectories (e.g., WEs, EEs. The 30\% of high-ozone events associated with Dv were often connected with the second-stage clusters with longer trajectories (e.g., WEl, EEl).

The relationships between weather types and long-range transport patterns became more clear and significant when we analyzed their annual frequencies (Table 2). The detrended (by removing the linear trend in time) values for high-ozone events, weather types, and trajectory clusters were analyzed in order to eliminate the influences from trend-induced correlations. Statistically significant correlations were found between the annual counts of high-pressure systems (Av) and those of VIC in summer. In addition, even stronger anticorrelations occurred between the annual counts of low-pressure systems $(\mathrm{Cv})$ and those of VIC. This emphasized the strong link between stagnant weather conditions and high-ozone events, especially in the

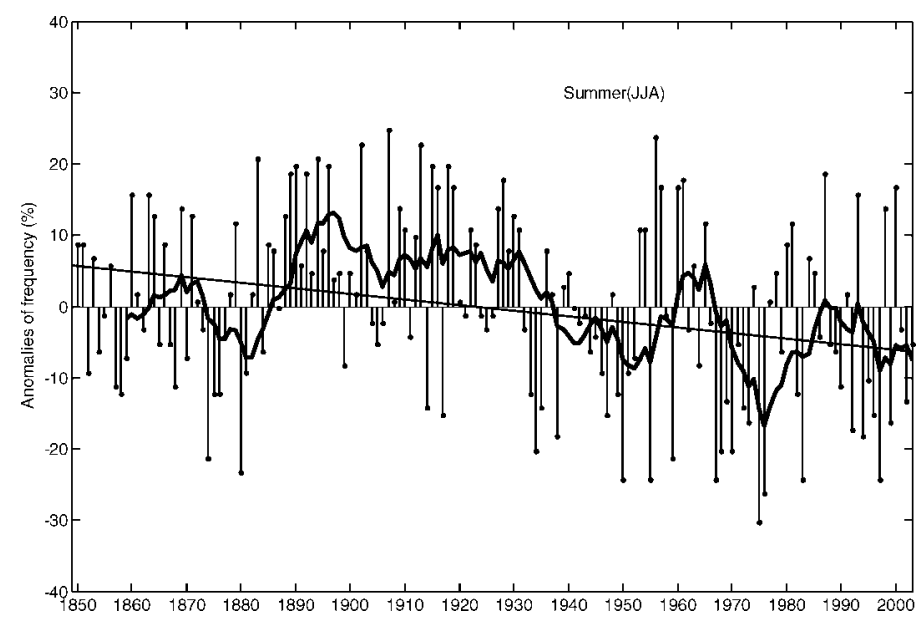

Figure 5. Trend for the frequency of anomalies for cyclonic and its hybrid (Cv) weather types during the summer (June-August) over the past 150 y $(1850-2003)(P<0.01)$. summer. Unstable weather conditions, which are associated with low-pressure systems, tend to diffuse or dilute surface ozone and its precursors.

In the spring, however, such high correlations between annual counts of trajectory clusters and anticyclonic (Av) and cyclonic $(\mathrm{Cv})$ weather types were not present (Table 2), despite the high anticorrelation between the annual counts of $\mathrm{Cv}$ and Av ( -0.89 in spring, $\mathrm{P}<0.001 ;-0.87$ in summer, $\mathrm{P}<0.01)$. The influences of synoptic circulation on high-ozone events seemed to be disturbed by perturbations from other processes that occurred in the spring. One of these perturbations might be stratospheric injection, which may become significant due to springtime maximum in upper-level cyclongenesis (the development of midlatitudes cyclone) and tropopause folding events (34).

\section{Indicators for High-ozone Events during Summer (June- August 1990-2006)}

The relationships between weather types and long-range transport patterns from 1996-2005 illustrated the strong links of high-pressure systems, atmospheric stagnation, and highozone events, as well as the negative effects of low-pressure systems, on high-ozone events in the summer. To assess the influence of the weather types on regional air quality, we examined the frequency of cyclonic weather types $(\mathrm{Cv})$ and annual ozone variations at Rörvik/Råö, Norra Kvill, and Vavihill with a longer time series from 1990-2006. The annual counts of $\mathrm{Cv}$ have a significant anticorrelation (Table 3) and strong linear relationships (Fig. 4) with the counts of highozone events, as well as with the annual mean daily maximum 8hr ozone concentrations (Table 3). The frequency of cyclonic weather type can thus be considered as an indicator of low risk for summertime high-ozone events in southern Sweden.

\section{DISCUSSION}

The relationship between daily LWTs and daily mean surface ozone has been shown in a recent study by using the LambJenkinson weather types in southern Sweden (16). This study further established that the frequency of $\mathrm{Cv}$ can be used as a strong indicator for the occurrence of high-ozone events in the summer. Leibensperger et al. (35) also concluded that midlatitude cyclone frequency can be used as a meteorologic predictor for air quality in the northeastern U.S. Because atmospheric circulation can be robustly simulated by general circulation models, this feature of midlatitude cyclone is providing a simple tool to probe the effect of climate change on regional air quality (35).

Suppose that $\mathrm{Cv}$ works as an indictor of high-ozone events in southern Sweden. In such a case, the potential impact of atmospheric circulation on surface ozone can be assessed by checking the long-term change of this weather type. The weather types over southern Sweden from 1850-2003 were calculated based on the dataset provided by the EMULATE project. The frequency of $\mathrm{Cv}$ decreased significantly $(\mathrm{P}<0.01)$ during the summer over the past $150 \mathrm{y}$ (Fig. 5). If this trend continues, more high-ozone events in southern Sweden will occur regardless of the influences from other factors, such as emissions of ozone precursors.

Indeed, a decrease in the frequency of northern midlatitude cyclones has been indicated by both modeling and the observational record $(36,37)$. The weather is becoming more stagnant because of weaker global circulation, and a decreasing frequency of midlatitude cyclones is expected on a global scale (38). In the northeastern U.S., the extreme climatic conditions (sunny, warm, and dry) were the underlying cause for the 
significant difference in the number of ozone episodes (39). In Europe, the extreme weather events, such as the summer heat wave in 2003, may become more frequent in the future (10).

\section{CONCLUSIONS}

The main aim of this study was to link the Lamb-Jenkinson weather types with long-range transport patterns to provide a quantitative, mechanistic basis for the correlation between synoptic weather types and regional ozone concentrations. The main approach was to apply a statistical cluster analysis of air mass trajectories. A short, whirling transport cluster could be associated with high-ozone events that occurred under Av. This confirms the strong relationship between stagnant weather conditions and high-ozone events identified in previous studies. At the same time, this study also identified a strong, negative, linear relationship between the annual counts of cyclones and the annual count of summer high-ozone events. This provides a potential tool to assess the possible effects of climate change on surface ozone concentrations. However, springtime ozone concentrations did not show as strong relationships with synoptic weather patterns as did summer ozone concentrations.

\section{References and Notes}

1. Prather, M., Gauss, M., Berntsen, T., Isaksen, I., Sundet, J., Bey, I., Brasseur, G., Dentener, F., et al. 2003. Fresh air in the 21 st century? Geophys. Res. Lett. 30, 1100 (doi: 10.1029/2002GL016285)

2. Simmonds, P.G., Derwent, R.G., Manning, A.L. and Spain, G. 2004. Significant growth in surface ozone at Mace Head, Ireland, 1987-2003. Atmos. Environ. 38, 4769-4778.

3. Laurila, T., Tuovinen, J.-P., Tarvainen, V. and Simpson, D. 2004. Trends and scenarios of ground-level ozone concentrations in Finland. Boreal Env. Res. 9, 167-184.

4. Carslaw, D.C. 2005. On the changing seasonal cycles and trend of ozone at Mace Head, Ireland. Atmos. Chem. Phys. 5, 3441-3450.

. Derwent, R.G., Simmonds, P.G., Manning, A.J. and Spain, T.G. 2007. Trends over a 20-year period from 1987 to 2007 in surface ozone at the atmospheric research station, Mace Head, Ireland. Atmos. Environ. 9091-9098.

6. Solberg, S., Derwent, R.G., Hov, Ø., Langner, J. and Lindskog, A. 2005. European abatement of surface ozone in a global perspective. Ambio 34, 47-53.

Vestreng, V. 2003. Review and Revision-Emission Data Reported to CLRTAP. EMEP MSC-W Note $1 / 2003$.

8. Solberg, S., Bergstrom, R., Langner, J., Laurila, T. and Lindskog, A. 2005. Changes in Nordic surface ozone episodes due to European emission reductions in the 1990s. Atmos. Environ. 39, 179-192.

9. Meleux, F., Solmon, F. and Giorgi, F. 2007. Increase in summer European ozone amounts due to climate change. Atmos. Environ. 41, 7577-7587.

10. Solberg, S., Hov, Ø., Søvde, A., Isaksen, I.S.A., Coddeville, P., De Backer, H., Forster, C., Orsolini, Y., et al. 2008. European surface ozone in the extreme summer 2003.J. Geophys. Res. 113, D07307. (doi: 10.1029/2007JD009098)

11. Grennfelt, P. and Hov, Ø. 2005. Regional air pollution at a turning point. Ambio 34, 2 10.

12. Stohl, A. and Trickl, T. 1999. A textbook example of long-range transport: simultaneous observation of ozone maxima of stratospheric and North American origin in the free troposphere over Europe. J. Geophys. Res. 104, 30445-30462

13. Tarasova, O.A., Elansky, N.F., Kuznetsov, G.I., Kuznetsova, I.N. and Senik, I.A. 2003. Impact of air transport on seasonal variations and trends of surface ozone at Kislovodsk high mountain station. J. Atmos. Chem. 45, 245-259.

14. Cape, J.N., Methven, J. and Hudson, L.E. 2000. The use of trajectory cluster analysis to interpret trace gas measurement at Mace Head, Ireland. Atmos. Environ. 34, 3651-3663.

5. Lindskog, A., Karlsson, P.E., Grennfelt, P., Solberg, S. and Forster, C. 2007. An exceptional ozone episode in northern Fennoscandia. Atmos. Environ. 41, 950-958.

16. Tang, L., Chen, D., Karlsson, P.E., Gu, Y. and Ou, T. 2009. Synoptic circulation and its influence on spring and summer surface ozone concentrations in southern Sweden. influence on spring and sum
Boreal Env. Res. 14, 889-902.

17. O'Hare, G.P. and Wilby, R. 1995. A review of ozone pollution in the United Kingdom and Ireland with an analysis using Lamb Weather Types. Geogr. J. 161, 1-20.

18. NILU. 2009. Flextra - Air mass trajectories. (http://tarantula.nilu.no/trajectories, accessed 23 November 2009)

19. Lamb, H.H. 1950. Types and spells of weather around the year in the British Isles. Quart. J. Roy. Meteor. Soc. 76, 393-438

20. Jenkinson, A.F. and Collison, F.P. 1977. An initial climatology of gales over the North Sea. In: Synoptic Climatology Branch Memorandum, No. 62. Meteorological Office, Bracknell, UK, 18 pp

21. Chen, D. 2000. A monthly circulation climatology for Sweden and its application to a winter temperature case study. Int. J. Climatol. 20, 1067-1076.

22. Kalnay, E., Kanamitsu, M., Kistler, R., Collins, W., Deaven, D., Gandin, L., Iredell, M., Saha, S., et al. 1996. The NCEP/NCAR 40-Year Reanalysis Project. Bull. Amer. Meteor. Soc. 77, 437-471.

23. Ansell, T.J., Jones, P.D., Allan, R.J., Lister, D., Parker, D.E., Brunet, M., Moberg, A., Jacobeit, J., et al. 2006. Daily mean sea level pressure reconstructions for the European-North Atlantic region for the period 1850-2003. J. Climate 19, 27172742. (doi: 10.1175/JCLI3775.1)

24. Stohl, A., Wotawa, G., Seibert, P and Kromp-Kolb, H. 1995. Interpolation errors in wind fields as a function of spatial and temporal resolution and their impact on different types of kinematic trajectories. J. Appl. Meteor. 34, 2149-2165.

25. Stohl, A. and Seibert, P. 1998. Accuracy of trajectories as determined from the conservation of meteorological tracers. O.J.R. Meteorol. Soc. 125, 1465-1484

26. European Centre for Medium Range Weather Forecasts. (http://www.ecmwf.int, accessed 23 November 2009)

27. Stohl, A. 1998. Computation, accuracy and applications of trajectories-a review and bibliography. Atmos. Environ. 32, 947-966.
28. Abdalmogith, S.S. and Harrison, R.M. 2005. The use of trajectory cluster analysis to examine the long-range transport of secondary inorganic aerosol in the UK. Atmos. Environ. 39, 6686-6695.

29. Coury, C. and Dillner, A. 2007. Trends and sources of particulate matter in the Superstition Wilderness using air trajectory and aerosol cluster analysis. Atmos. Environ. 41, 9309-9323.

30. Gu, Y. 2008. Trajectory Cluster Analysis of Ozone Episodes in Southern Sweden during 1997-2005. Masters Thesis for Atmospheric Science, University of Gothenburg, Gothenburg, Sweden.

31. Borge, R., Lumbreras, J., Vardoulakis, S., Kassomenos, P. and Rodriguez, E. 2007. Analysis of long-range transport influences on urban PM10 using two-stage atmospheric trajectory clusters. Atmos. Environ. 41, 4434-4450.

32. Dorling, S.R., Davies, T.D. and Pierce, C.E. 1992. Cluster analysis: a technique for estimating the synoptic meteorological controls on air and precipitation chemistrymethod and applications. Atmos. Environ. 26, 2575-2581

33. Dorling, S.R. and Davies, T.D. 1995. Extending cluster analysis-synoptic meteorology links to characterise chemical climates at six northwest European monitoring stations. Atmos. Environ. 29, 145-167.

34. Monks, P.S. 2000. A review of the observations and origins of the spring ozone maximum. Atmos. Environ. 34, 3545-3561.

35. Leibensperger, E.M., Mickley, L.J. and Jacob, D.J. 2008. Sensitivity of US air quality to mid-latitude cyclone frequency and implications of 1980-2006 climate change. Atmos. Chem. Phys. 8, 7075-7086.

36. Geng, Q.Z. and Sugi, M. 2003. Possible change of extratropical cyclone activity due to enhanced greenhouse gases and sulfate aerosols — study with a high-resolution AGCM. enhanced greenhouse gase

37. Yin, J.H. 2005. A consistent poleward shift of the storm tracks in simulations of $21 \mathrm{st}$ century climate. Geophys. Res. Lett., L18701. (doi: 10.1029/2005GL023684)

38. Jacob, D.J. and Winner, A.D. 2009. Effect of climate change on air quality. Atmos. Environ. 43, 51-63.

39. White, A.B., Darby, L.S., Senff, C.J., King, C.W., Banta, R.M., Koermer, J., Wilczak, J.M., Neiman, P.J., et al. 2007. Comparing the impact of meteorological variability on surface ozone during the NEAQS (2002) and ICARTT (2004) field campaigns. $J$ Geophys. Res. 112, D10S14. (doi: 10.1029/2006JD007590)

40. We acknowledge the Norwegian Institute for Air Research (NILU) for providing the FLEXTRA trajectories (http://www.nilu.no/trajectories) used in this study. Air mass trajectories were calculated using the FLEXTRA model developed by Andreas Stohl (NILU) in cooperation with Gerhard Wotawa and Petra Seibert (Institute of Meteorology and Geophysics, Vienna) and using meteorologic data provided from the Meteorology and Geophysics, Vienna) and using meteorologic data provided from the European Centre for Medium-Range Weather Forecast. We thank Dr. Christine
Achberger and Tinghai Ou for calculating and providing Lamb weather types over Achberger and Tinghai Ou for calculating and providing Lamb weather types over
southern Sweden during 1850 to 2003 and 1990 to 2006, respectively. Also, we would like very much to express our great thanks to the editor and referees for valuable suggestions and comments to improve our manuscript

Lin Tang has a PhD in the field of Environmental Science. She works with ambient ozone and its precursors in urban and regional air pollution, air pollution modelling and its application. Her address: University of Gothenburg, Department of Earth Sciences, P.O. Box 460, SE-405 30 Göteborg, Sweden.

E-mail: lin.tang.gu@gmail.com

Per Erik Karlsson is an associate professor in Plant Physiology. His main research interests are variations of air pollutant concentrations and deposition in the landscape and their impacts on forest ecosystems as well as carbon sequestration by forests. His address: Swedish Environmental Research Institute Ltd., P.O. Box 5302, SE-400 14 Göteborg, Sweden. E-mail: pererik.karlsson@ivl.se

Yongfeng $\mathrm{Gu}$ has a MSc in Atmospheric Environment. His research is focused on trajectory and cluster analysis for ozone episodes in southern Sweden. His address: University of Gothenburg, Department of Earth Sciences, P.O. Box 460, SE-405 30 Göteborg, Sweden.

E-mail: guyongf@ hotmail.com

Deliang Chen is a professor in Physical Meteorology at University of Gothenburg. His research area deals with regional climate change and variability in Sweden and China, statistical and dynamic downscaling, climate dynamics, boundary-layer and local climatology with emphasis on surface processes, air pollution, and geostatistics. He is now the Executive Director of the International Council for Science (ICSU). His address: 5 rue Auguste Vacquerie, F-75116 Paris, France.

E-mail: deliang@gvc.gu.se

Peringe Grennfelt is a Scientific Director of IVL (Swedish Environmental Research Institute) and adjunct professor in atmospheric chemistry at University of Gothenburg. His main interest is atmospheric chemistry in relation to regional air pollution and its policy development. His address: Swedish Environmental Research Institute, P.O. Box 5302, SE-40014 Göteborg, Sweden.

E-mail: peringe.grennfelt @ivl.se 